\title{
History of fires and vegetation since the Neolithic in the Cantabrian Mountains
}

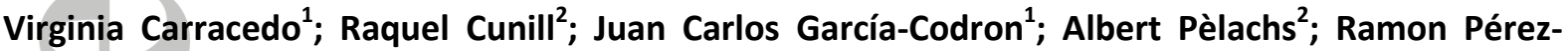 Obiol'; Joan Manuel Soriano $^{2}$}

${ }^{1}$ Department of Geography, Urban Studies and Land Planning, Avenida de Los Castros s/n, Universidad de Cantabria, 39005 Santander, Spain

${ }^{2}$ Department of Geography, Edifici B, Facultat de Filosofia i Lletres, Universitat Autònoma de Barcelona, 08193 Bellaterra (Cerdanyola del Vallès), Spain

${ }^{3}$ Botany Unit, Department of Animal Biology, Plant Biology, and Ecology, Universitat Autònoma de Barcelona, 08193 Bellaterra (Cerdanyola del Vallès), Spain

\begin{abstract}
Fire has been one of the main causes of disturbance of vegetation over time, and since the Neolithic has become an irreplaceable tool for the opening of forest spaces and maintenance of pastures. Previous studies showed that the intensity and effects of wildfires are related to the biomass and controlled by climate factors. However, in regions such as Cantabria, where agriculture and livestock have spread throughout the territory since prehistory, fires should also be closely related to human land uses. The aim of this paper was to investigate the history of fires and vegetation since the Neolithic in the Cantabrian Mountains, using sedimentary charcoals and pollen data to study the role of human activities in the processes that have shaped ecosystems throughout the Holocene. The asynchrony and quantitative differences in the results obtained at different sites indicate significant variations in fire patterns at regional scale since the Neolithic, although the type and size of each basin also had a strong influence on charcoal accumulation. Maximum values for charcoal accumulation rate (CHAR) at La Molina were observed between the Neolithic and the Bronze Age, but occurred after about 3500 cal years BP at El Cueto de la Avellanosa. At El Sertal, low CHAR values were observed, probably because the sequence begins in a space that already had been cleared; the maximum values occurred during the most recent millennium. These data provide evidence that fire has been a key factor in forest retreat and in maintaining open landscapes since the Neolithic.
\end{abstract}

Key words: sedimentary charcoal, pollen, fire, climate, Neolithic, Cantabrian Mountains

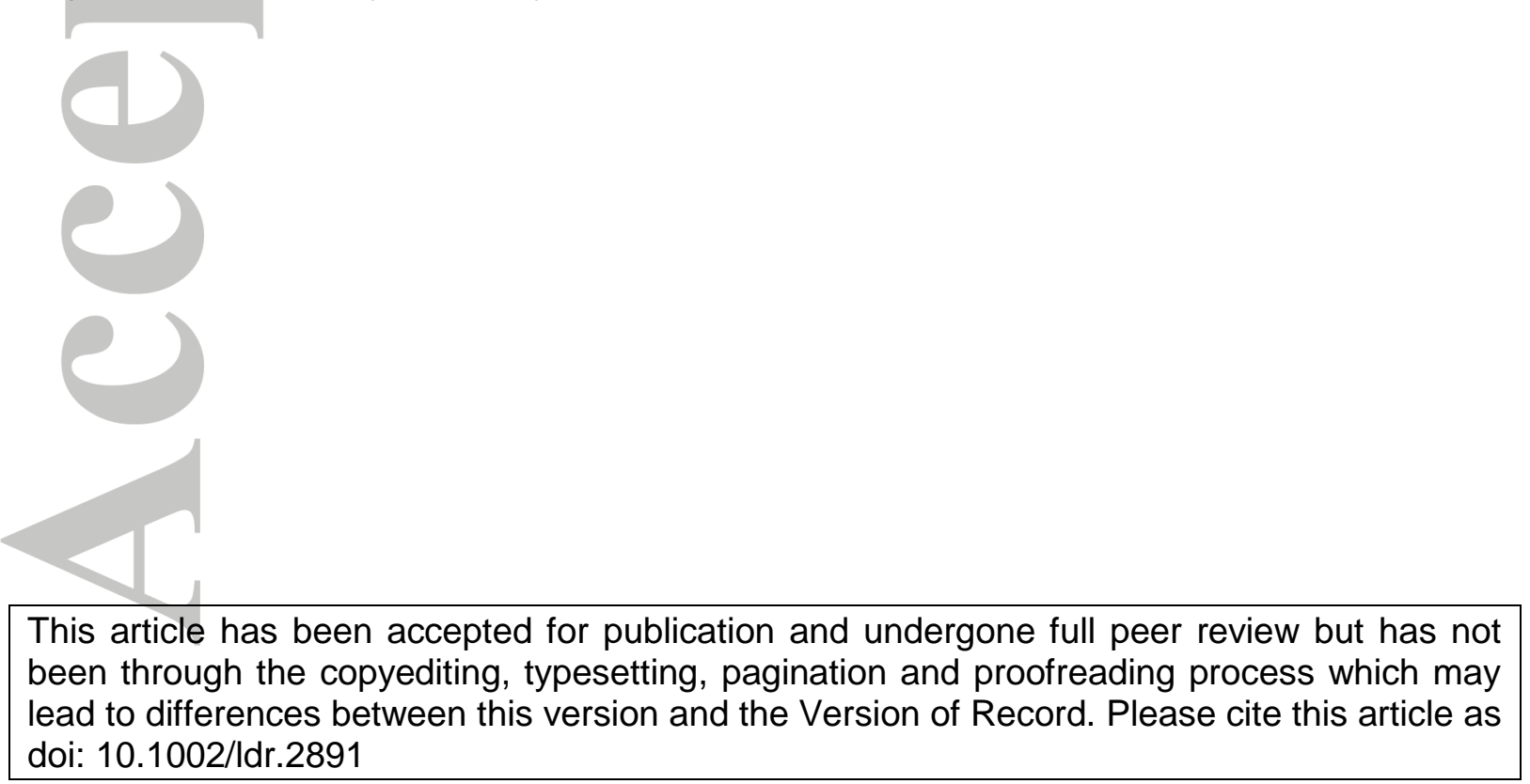

This article is protected by copyright. All rights reserved. 


\section{INTRODUCTION}

\section{Fire as an ecological factor}

In recent decades, research in ecosystems throughout the world has shown sedimentary charcoals to be a useful proxy helping to explain the role of fire as a key ecological factor (Whitlock \& Larsen C, 2001; Power et al., 2008; Feurdean et al., 2012; Beffa et al., 2015). The impact of fire on the landscape during the Last Glacial and since the beginning of the Holocene has been analyzed in relation to climatic episodes and to the availability of biomass in various parts of the world, including central and southern Europe (Carcaillet et al., 2012; Gil-Romera et al., 2014; Rius et al. 2014; López-Sáez et al. 2017).

Fire signal and pollen data facilitate an understanding of historical disturbances in the landscape (Burjachs \& Expósito, 2015; González-Pellejero et al., 2014). As Conedera et al. (2009) report, the creation of effective land management approaches requires a sound understanding of past forest stands and of landscape dynamics. A well-grounded knowledge of the natural range of variability in the disturbances and processes that shaped ecosystems before the rapid intensification of human action in recent times is indispensable to achieve appropriate land management.

This knowledge can help researchers separate signs of climate change from human action by considering biomass availability, among other factors (Carcaillet et al., 2007) and understand the relationship between fire history and elevation-dependent parameters, biomass, and land management (Vannière et al., 2016).

Analysis of the deposition of sedimentary charcoal particles provides information on fuel availability, the extension of a historical fire, and the estimated distance between the fire and the coring site (Higuera et al., 2011; Ali et al., 2012). The fire regime can be inferred from the total number of charcoal particles per unit of sediment, which is proportional to the total biomass burned in a given site's surroundings (Marlon et al., 2006; Thevenon et al., 2004). Thus, sedimentary charcoals ( $\geq 150$ $\mu \mathrm{m}$ ) have been used in the study of long-burning fire events (local scale fire, $500 \mathrm{~m}-1 \mathrm{~km}$ ) in mountain zones (Clark, 1988). Fires in European mountain zones have been studied in the Alps (Carcaillet et al., 2007), Pyrenees (Rius et al., 2011; Bal et al., 2011) and the Iberian Central System (López-Sáez et al. 2017). Considering the available evidence since the Neolithic period, fire appears to be a great ally for the opening of forest spaces and the maintenance of open landscapes (Cunill et al., 2012, Feurdean et al., 2012, Gil-Romera et al., 2014; Colombaroli et al., 2014, García-Amorena et al. 2017), a practice that survives in Cantabria to the present day (Carracedo, 2015).

In Cantabria, only one study of historical fires has been based on sedimentary charcoals (Pérez-Obiol et al., 2016); it points out the importance of fire since Neolithic times in one of the Iberian regions most affected by fires in forests and pasture lands. The region also has some of the richest and best known prehistoric archaeology in Europe (Moure Romanillo, 1995; González-Morales \& Estévez, 2004).

At present in Cantabria, fires are generally intentional and mainly burn scrub (Carracedo, 2015); previously, tree biomass was involved but controlled by climate factors. For example, Bond cycles (Bond et al., 2001) associated with quasi-periodic climate fluctuations have sometimes coincided with cooling periods or dry periods (Burjachs and Expósito, 2015); in Cantabria, dry climatic phases coincided with Bond cycles 3 and 4 (Pérez-Obiol et al., 2016), which could favor greater recurrence of fires.

Although it has been assumed that fire synchronicity is linked to climate, there may be a correlation with a human factor linked to land use. The type of landscape at each site and the role of biomass in fire history can be assessed by pollen analysis. The main objective of this study was to analyze the history of fires and vegetation since the Neolithic in the Cantabrian Mountains using sedimentary charcoals and pollen data in core samples obtained from three peat bogs (La Molina, El Sertal and el Cueto de la Avellanosa). In order to make reliable comparisons, the synchronicity of fire episodes

This article is protected by copyright. All rights reserved. 
and the observed differences associated with altitude, as well as topographic factors and human activities, were included in the analysis.

\section{Study area}

The peat bogs analyzed are located in the central-western sector of Cantabria, in northern Spain (Fig.1). The Cantabrian Mountains are an obstacle to the prevailing winds of maritime origin and give rise to a strong climatic dissymmetry. The northern slope has a temperate and rainy oceanic climate with seasonally distributed annual precipitation totals ranging from 1000 to $1600 \mathrm{~mm}$ (Cfb, in the Köppen-Geiger classification), while the southern slope shows continental Mediterranean traits (Csb) with cold winters and a water deficit in the summer. The highest sectors have a narrow, intercalated strip of mountainous climate (Dfc / Dsb / Dsc), with annual precipitation -occurring in the form of snow for much of the year- that may exceed $2000 \mathrm{~mm}$ (AeMet, 2011).

The Cantabrian Mountains mark the border between the Euro-Siberian and Mediterranean biogeographical regions (characterized by deciduous broad-leaved and evergreen forests, respectively), which in turn have different features depending on the vegetation floor or local substrate. On the oceanic slope, the vegetation of the lower zones is drawn from a mixed thermophilous forest dominated by Quercus robur, although on the limestone substrate there are also $Q$. ilex subsp. ilex forests and numerous Mediterranean taxa such as Phillyrea latifolia, Pistacia terebinthus, Olea europaea, and Viburnum tinus. Above 500 or 600 m.a.s.I., Quercus pyrenaica and Q. petraea occupy the southern slopes; on the northern slopes, Fagus sylvatica dominates at this altitude. The highest forests, which reach 1700 m.a.s.I. in altitude, include Quercus petraea, Ilex aquifolium, and Betula pubescens. On the Mediterranean side, the potential natural vegetation is dominated by semi-deciduous forests and sclerophyllous formations ( $Q$. pyrenaica and $Q$. ilex subsp. rotundifolia). At present there are no natural coniferous forests in Cantabria, although several pine species have been planted and are now common in the region (Fig. 2).

La Molina peat bog (43015'38" N-3o 58'37" W; ETRS89) is located at 484 m.a.s.l. in the municipality of Puente Viesgo, $20 \mathrm{~km}$ from the Cantabrian coast. It occupies a topographical concavity oriented to the North in the Pas-Besaya divide, currently dominated by minerotrophic wetlands and some small ombrotrophic areas. Moist Atlantic heaths of Erica ciliaris and E. tetralix are predominant, although Quercus robur remains with Betula pubescens and Alnus glutinosa are preserved on the slopes. El Sertal $\left(43^{\circ} 13^{\prime} 0.23^{\prime \prime} N 4^{\circ} 26^{\prime} 16^{\prime \prime} \mathrm{W}\right)$ is located on a small mountain range, at 940 m.a.s.l., near Peña Sagra. The peat bog is in a mountain pass, in an elevated, well-ventilated area without lateral protections (Mariscal, 1986). Communities of Nardus stricta dominate locally, and nearby are moist Atlantic heaths with E. ciliaris and E. tetralix and some remains of Quercus pyrenaica and Q. robur. EI Cueto de la Avellanosa (43 06 '50" N 40 21' 52" W) also lies in a mountain pass, located at 1320 m.a.s.l. on the northern slope of the Cordel range. It rests on a substrate of impermeable sandstone, forming weak aqueous layers in which Sphagnum grows (Mariscal, 1983). At present, the communities of Nardus stricta and oro-Mediterranean and dry European heaths dominate, while on the slopes there are forests of Fagus sylvatica and Betula pubescens.

This article is protected by copyright. All rights reserved. 


\section{Archaeological context}

The archaeological heritage of Cantabria is exceptionally rich and provides us with abundant information on the ways of life and the use of the territory in the region throughout the period between the Late Palaeolithic (late Pleistocene s.I.) and the end of Prehistory (Fig. 1).

Most of the remains dating to the Palaeolithic have been found in low valleys and coastal areas but this situation changes in the Neolithic, throughout the sixth millennium B.P., with the appearance of the first groups of herders and farmers who quickly colonized most of the regional territory (see Table 1). Subsequently, an economy based on cattle ranching and the exploitation of mountain areas was consolidated, leading to an effective system of spatial and productive organization that is considered the direct antecedent of the one that has survived until the contemporary period (Ortega, 1984). Knowledge about this historical process of cultural evolution and colonization of the territory provides a large amount of proxy data of great value for understanding the results obtained in relation to the use of fire and the evolution of the vegetation in the region.

Copper and tin deposits are very scarce in Cantabria; the region was relatively isolated from the new cultural currents and no important economic or social changes occurred during the Bronze Age (Blas and Fernández, 1992). However, we know that during this period (ca 3800 - 2700 cal years BP), peasant societies continued their consolidation and agricultural and livestock farming activities experienced strong growth, which encouraged the occupation of new areas (Arias, 1999).

Archaeology of the Iron Age is also very limited in this region (Arias, 1999; Blas and Fernández, 1992). There is evidence of large deforested areas at mid-mountain summits. The population was distributed throughout the region in small fortified nuclei situated in easy-to-defend positions, such as hydrographic boundaries or high points that allowed a good control of the territory. This settlement system was likely the most common until Roman times (Peralta, 2000; Cisneros et al., 2008).

Along the entire coastal strip of the region, numerous deposits of goethite, pyrite, hematite, limonite and other iron ores have been exploited uninterruptedly from the beginning of the Iron Age to the contemporary era. This activity was particularly intense and widespread during Roman times (Mantecón, 2000) and much later, between the 16th and 19th centuries. In addition, various lead and zinc minerals (mainly galena and sphalerite) were likely mined, and mining of other metals and metallurgy (especially iron) also occurred, with extractive and processing activity concentrated in the east, south of the Bay of Santander and the Cartes area, very close to La Molina peat bog.

Finally, in historical times and until the nineteenth century, both extraction and charcoal smelting required enormous amounts of wood. This was another of the causes of forest retreat and transformation in the wake of the Iron Age (Ceballos, 2001).

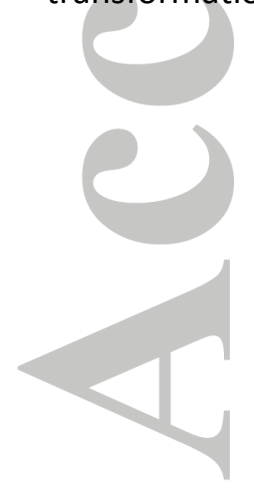

This article is protected by copyright. All rights reserved. 


\section{MATERIAL AND METHODS}

\section{Coring, samples, and chronology}

Samples were collected manually at La Molina and El Sertal by driving a 3-m PVC tube, $110 \mathrm{~mm}$ in diameter, to a depth of $260 \mathrm{~cm}$ and $50 \mathrm{~cm}$, respectively. At El Cueto de la Avellanosa, it was possible to take advantage of the vertical cut that remained accessible after exploitation of the peat bog was abandoned to a depth of $406 \mathrm{~cm}$. Cores from La Molina and El Sertal were cut into 302 and 57 samples, respectively, below the centimeter. At El Cueto de la Avellanosa, the core was sampled every seven centimeters for a total of 58 samples.

The chronology of the present study was based on 11 AMS ${ }^{14} \mathrm{C}$ dates (Beta Analytic Inc.) (Table 2, AC), calibrated at $2 \sigma$ from the INTCAL13 database (Reimer et al., 2013) using Calib Rev. 7.0.4. At La Molina, the dating did not respond to parametric adjustment. Therefore, an age-depth model was developed using Clam modeling software (Blaauw, 2010) with the R statistical software platform ( Core Team, 2015). Models for El Sertal and El Cueto de la Avellanosa underwent polynomial adjustment to obtain age-depth models (Fig. 3).

\section{Macroscopic charcoal analysis and organic matter content}

All samples from each site were used for the analysis of sedimentary charcoal and organic matter, for a total of 302 from La Molina, 57 from El Sertal, and 58 from El Cueto de la Avellanosa. To identify fire events, the number of charcoals $\geq 150 \mu \mathrm{m}$ was estimated (Carcaillet et al., 2001) in the Physical Geography laboratory of the Geography Department at the Universitat Autònoma de Barcelona. This charcoal particles approach does not allow taxonomic identification but does establish the relative magnitude of fire events. The standard protocol (Carcaillet et al., 2001, 2007), as adjusted by Pérez-Obiol et al. (2016), was followed. $\mathrm{KOH}$ was used as a deflocculant solution, and $15 \% \mathrm{NaClH}$ as a bleaching solution (Finsinger et al., 2014). Samples were heated to $70^{\circ} \mathrm{C}$ for 90 minutes and sieved with a $150 \mu \mathrm{m}$ mesh. The number of macroscopic carbon particles was estimated under a stereomicroscope at 40x. The surface area of charcoal fragments was estimated using an ocular grid with 100 squares of $0.0625 \mathrm{~mm} 2$ each. Charcoal fragments were classified into exponential size-classes according to their area. (Carcaillet et al., 2007). The sedimentary charcoals concentration (CHAC, $\mathrm{mm}^{2} / \mathrm{g}$ ) was used to obtain the charcoals accumulation rate (CHAR, $\mathrm{mm}^{2} / \mathrm{g} / \mathrm{yr}$ ), based on the sedimentation rate estimated by age-depth models for each site (Fig. 3, Fig. 4, and Fig. 5). Due to the high resolution of La Molina sedimentary charcoals, the CharAnalysis software (Higuera et al., 2009) was used to calculate fire frequency values for a 1000 -year window, along with charcoal peak distribution and magnitude. The resulting interpolation value was 17 years. Lowfrequency CHAR was modeled using a 1000-year running mean with a LOWESS smoothing function. Charcoal peaks were identified as peaks exceeding the 99th percentile of the noise distribution.

To allow a comparison of the three sites, their CHAR values were rescaled (Fig. 6) according to Power et al. (2008) using a minimax transformation. Briefly, this method rescales charcoal values from a given site record to range between 0 and 1 by subtracting from each charcoal value the minimum charcoal value found in the record, and dividing by the range of values.

Loss on ignition (LOI) analysis was carried out in the Physical Geography laboratory of the Geography Department at the Universitat Autònoma de Barcelona, modifying the standard procedures to achieve combustion at 550ㄷ for 4 hours (Dean, 1974 and Heiri et al., 2001). 


\section{Palynology}

Information from La Molina (Pérez-Obiol et al., 2016) and El Cueto de la Avellanosa (Mariscal, 1983) allowed us to obtain a complete and comparative view of vegetation changes. The pollen diagram was based on the 57 samples from El Sertal and the 151 samples taken from the top of La Molina.

In El Sertal peat bog, on the basis of the pollen data provided by Mariscal (1986), a new pollen analysis (adding NPP data) was done in order to obtain a better resolution of changes in that landscape. Sediment samples were prepared in the Palynological Analysis Laboratory, Department of Animal Biology, Plant Biology, and Ecology (BAVE) at the Universitat Autònoma de Barcelona according to standard chemical procedures (Moore et al., 1991), including treatment with $10 \% \mathrm{HCl} /$ $10 \% \mathrm{KOH} / 70 \% \mathrm{HF}$ to remove carbonates and silicates, followed by mounting with glycerol. Pollen was identified under an optical microscope using reference collections and codes (Reille, 1992 and 1998). The results were expressed in relative percentages, excluding aquatic plants and spores from the total sum. The pollen diagram was constructed using TILIA and TILIAGRAPH software (Grimm, 1991).

\section{RESULTS}

\section{Charcoal analysis and fire regime}

All three of the peat bogs have charcoal particles from the base (7000 cal years BP) up to the top layer. The presence of charcoals is almost uninterrupted at El Cueto de la Avellanosa and La Molina. At El Sertal, there was much more discontinuity in charcoal sediment. The highest CHAR values were observed at La Molina (a maximum of $2.63 \mathrm{~mm}^{2} / \mathrm{g} / \mathrm{yr}$ ), while at El Sertal the maximum was 0.010 $\mathrm{mm}^{2} / \mathrm{g} / \mathrm{yr}$ and at El Cueto de la Avellanosa, $0.326 \mathrm{~mm}^{2} / \mathrm{g} / \mathrm{yr}$ (Fig. 4, 5 and 6).

At La Molina (Fig. 4), the CHAR record was separated into five patterns: 1) From 6500 to $5800 \mathrm{cal}$ years BP, the CHAR was initially low, generally under $0.5 \mathrm{~mm}^{2} / \mathrm{g} / \mathrm{yr}$, with only one distinguishable peak and fire frequency not exceeding 2 fires $/ 1000 \mathrm{yr} ; 2$ ) The highest number of fires of the study period ( $>3$ fires $/ 1000 \mathrm{yr}$ ) occurred between 5800 and 3500 cal years BP, with seven CHAR peaks and CHAR values exceeding $\left.1.5 \mathrm{~mm}^{2} / \mathrm{g} / \mathrm{yr} ; 3\right)$ From 3500 to 2100 cal years $\mathrm{BP}$, the fire frequency oscillated between 2 and 3 fires/1000 yr, with 4 char peaks but a lower CHAR value, not exceeding $0.5 \mathrm{~mm}^{2} / \mathrm{g} / \mathrm{yr}$; 4) Between 2100 and 600 cal years BP, charcoal sediments decreased, with only two isolated CHAR peaks, low CHAR values, and a mean frequency of about 2 fires/1000 yr; 5) From 600 cal years BP until the present, the frequency of fires has increased notably, to 4 fires/1000 yr; CHAR values again reaching $0.5 \mathrm{~mm}^{2} / \mathrm{g} / \mathrm{yr}$, with two CHAR peaks.

In El Sertal (Fig. 5A), the lack of continuity and resolution in the charcoal sediment record impeded the establishment of a clear pattern for the last 7000 cal years BP. Testimonial evidence of charcoal presence was observed for 7000, 6400, 4900, 4300, 2800, 2150, 1800 and 1000 cal years BP, with a maximum presence during the Middle Ages and a strong presence during the most recent 400 years. CHAR values very slightly refined the $\mathrm{CHAC}$ results.

On the other hand, the presence of charcoals at El Cueto de la Avellanosa (Fig. 5B) was nearly uninterrupted throughout all the samples and the following patterns could be established : 1) From 7000 to 6300 cal years BP, mean CHAR values were $0.1 \mathrm{~mm}^{2} / \mathrm{g} / \mathrm{yr}$, comparable to those observed since the Middle Ages; 2) From 6300 to 5800 cal years BP, CHAR values were very low (the lowest of the entire sequence for this register); 3) From 5800 to 3600 cal years BP, CHAR values were low, with some secondary blips between 4800 and 5000 cal years BP; 4) From 3600 to 1000 cal years BP, the CHAR was the highest in the entire sequence, with a maximum peak of $0.326 \mathrm{~mm}^{2} / \mathrm{g} / \mathrm{yr}$ in $2650 \mathrm{cal}$ years $B P$ and CHAR values were often clearly above $0.10 \mathrm{~mm}^{2} / \mathrm{g} / \mathrm{yr}$. There was a secondary peak in the CHAR at c. 1700 cal years BP; 5) The most recent 1000 cal years BP were characterized by an increasing trend and higher mean CHAR values, compared to the rest of the study period. The highest values in this period were observed in the latest sample. 
A comparison of all the sequences (Fig. 6) showed a fire pattern that was differentiated but coincided with the main points when changes in trends were observed. This framework of trends was established between 3000 and 4200 cal years BP.

\section{Pollen analysis}

The pollen diagram for El Sertal (Fig. 7) indicates the main vegetation changes since Neolithic times. The arboreal pollen curve showed a decreasing trend throughout the entire sequence.

From 6700 to 4600 cal years BP, despite the highest values for arboreal pollen (mean value of 74\%) and a large Corylus presence, high percentages of Poaceae (up to $32 \%$ ) and Pteridium, as well as the presence of cereals, provided evidence of Neolithic human impact. Pine (probably Pinus sylvestris) was always less than $15 \%$ of the pollen values, which would not indicate the presence of pine forests in the vicinity.

Later on, at around 4600 cal years BP, the presence of Alnus increased, while hygrophilous taxa such as Cyperaceae found in the peat bog could be indicative of a lentic ecosystem. Cereals disappeared from the sequence until 3300 cal years BP. A continuous decline in tree cover and Corylus was observed.

Fagus sylvatica appeared about 3000 cal years BP and showed low percentage values (less than 2\%) for more than 2000 years. Arboreal pollen percentage values then continued to decrease, with a continuous curve of cereals, important Plantago values and rising values of Ericaceae.

In the past millennium, there was a strong increase in Fagus; this expansion of beech occurred at a time of decline in other trees and of increased human pressure in the Cantabrian Mountains (Muñoz-Sobrino et al., 2009). At the same time, anthropic pollen indicators acquire very high values. During the most recent centuries, an open landscape has dominated at the sites analyzed in the present study, with maximum Ericaceae, cereals, and Plantago values. The considerable Glomus values indicate erosion processes nearby, and Corylus has the lowest percentage values observed in the last 6700 years.

\section{Discussion}

\section{Patterns of charcoal accumulation and relationship with type of basin}

The charcoal sediment records obtained allow a characterization of each site and show great variation on a regional scale in the patterns of fires since the Neolithic period. Sedimentologically, the three sites did not show abrupt changes during the Holocene. In La Molina and El Sertal, there are significant inflections in the quantity of organic matter that could reflect periods of erosion and produce major changes in the numerical values of the charcoals (Thevenon et al., 2003). However, in our data, the charcoal peaks did not normally coincide with greater energy in the sediment inputs to the basin (Fig. 3). In La Molina, there was an inverse proportion between the recent Holocene erosion processes and the sedimentary charcoal values.

The quantitative differences between the three sites may be due to several factors: basin type and size, patterns and rate of deposition, number of woody plants burned, and anthropic factors (Rius et al., 2011). In the present study, basin type seems to have a lot of weight. Macroscopic charcoal is usually not carried more than a few hundred meters and therefore is mainly a local fire proxy (Whitlock and Larsen, 2001; Higuera et al., 2007; Ohlson and Tryterud, 2000; Clark, 1988). The concave La Molina topography could have contributed to the quantitative results of charcoal particle deposits, both locally and on the slopes that form the basin. However, El Sertal and El Cueto de la Avellanosa occupy two hills and have almost no basin to receive particles from nearby slopes. This difference shows the sensitivity of the sedimentary records to the morphology of each site, along with the importance of considering likely potential biases (Higuera et al., 2005). 


\section{Fire regime}

Several Mediterranean and Pyrenean studies (Rius et al., 2009; Mercuri and Sadori, 2014; Sadori et al., 2015; Beffa et al., 2015) illustrate the main trends of interlaced forces acting on the development of the landscape during the Holocene. Joint actions of climate oscillations, increasing dryness, and human impact are hard to disentangle, and this becomes particularly true after the mid-Holocene onset of Bronze Age cultures (Rius et al., 2009; Vannière et al., 2011; Mercuri, 2014). Nevertheless, other studies found human impact on fire regime and frequencies since the Neolithic (8000 cal BP) (Vannière et al., 2008). Thus, the existence of dissimilar chronological patterns between the three peat bogs makes it difficult to interpret the data based solely on climate factors. However, the Cantabrian Region has been characterized by the predominance of broad-leaved forests since the beginning of the Holocene and by a large and sustained human presence since the Late Glacial period, which suggests that human control has been a major factor in the region's fires since the Neolithic.

At La Molina, the maximum fire values occurred between the Neolithic and the Bronze Age, when fire events would have been of great severity due to the availability of wood for fuel. Given the large number of charcoals and the high resolution of this record, fire peaks and their magnitude have been understood as providing a clearer visualization of fire events, indicating either high intensity or proximity.

Significant fire events were identified from the very base to the end of the sequence, with the highest frequency and intensity between 5800 and 3500 cal years BP (Fig. 4), coinciding with the highest arboreal pollen values. These data agree with studies carried out in a subcoastal area in the NW Iberian Peninsula, where there is evidence of frequent fires during the last 6300 years (Carrion et al., 2010). After 5500 cal years BP, the percentage of arboreal pollen decreased and Ericaceae pollen increased along with the opening of new agricultural spaces and episodes of "cultural" fires. The first part of the Bronze Age still shows pollen evidence of significant fire events.

The probability of fires is much greater if fuel, in the form of vegetal biomass, is combined with dry climatic conditions, so the oscillations associated with Bond cycle 4 (ca. 5500 cal years BP) could have favored the fires of the Neolithic period and those of Bond cycle 3 (ca. 4200 cal years BP), the fire episodes of maximum frequency. The mid-Holocene (around 8.0-4.2 ka BP) was a time of great instability due to increasing climate variability and cultural changes in many regions of the world (Mercuri and Sadori, 2014).

Despite a lower fire frequency during the last 3500 cal years BP, an increase was again observed during the most recent millennium. The pollen curve decreased steadily until about 2800 cal years $\mathrm{BP}$, about the time that fires were being used to maintain open agricultural spaces and there were fewer local fires with wood fuels. According to Pérez-Obiol et al. (2016), the increase in Poaceae and cereals since pre-Roman times is closely related to the absence of trees or shrubs as fuel for fires in the adjacent zones. In the final part of the sequence (Fig. 7), various anthropic or fire indicators (Ericaceae, Cerealia and Plantago) attest to pastures and crops dominating the landscape, as they do now.

The fire events detected at El Sertal and El Cueto de la Avellanosa (Fig. 5 and Fig. 6) appear to follow a different pattern, although the inflection and trend change points are the same as at La Molina. At El Cueto de la Avellanosa, CHAR increased ca. 3600 cal years BP and the maximum is seen at ca. 2650 years cal BP, coinciding with Bond cycle 2. The low CHAR values of El Sertal could be explained by an open space already present at the base of the sequence and the charcoal particles coming from woody fuel burning some distance away from the sampling point. Situated on a hill, it would only receive contributions from nearby fires. The highest CHAR values were found during the most recent millennium, when there has been a greater local and regional anthropic pressure. 
From 3000-2800 cal years BP, the percentage of Ericaceae pollen increased and arboreal pollen decreased simultaneously, a pattern very similar to El Cueto de la Avellanosa (Mariscal, 1983). At this site, the increase in sedimentary charcoals was more coincident with indicators of the opening of the landscape, which suggests either that the fires were closer to the site or that its basin better reflects the events. Mariscal (1983) points out the development experienced by the paraclimatic communities of areas deforested by human action as the most remarkable feature.

The period of transformation represented by the Bronze Age seems to correspond to a global pattern in mountain areas where the dominant vegetal landscape consisted of open spaces, with a predominance of vegetation of anthropic origin and pastures for livestock (Carozza et al., 2005; Ruiz Alonso et al., 2011). The signs of human pressure become even clearer thereafter, beginning 2800 cal years BP. This model of general intensification of anthropic pressure on high mountain environments is well documented for the Pyrenees and the Basque Country and seems to respond to a global pattern in the whole northern part of the Iberian Peninsula (Galop et al., 2007; Bal et al., 2011; Pèlachs et al., 2011; Gassiot et al., 2014).

\section{Fire and landscape dynamics}

The first fire episodes are inextricably linked with the important percentages of Poaceae and Pteridium as well as the presence of cereal pollen grains (between 6000 and 5000 cal years BP) stand out as indicating open spaces (Fig. 7). These agricultural practices are also evidenced by the presence of naked wheat grains in El Mirón cave during the Neolithic period (Peña-Chocarro et al., 2005). In Monte Areo, Asturias, the first evidence of human landscape transformation dates back 7300 years (López-Merino et al., 2010) and the appearance of a cereal-type pollen occurs between 6735-6495 cal years BP. The disappearance of cereals between 4800 and $3300 \mathrm{cal}$ years BP could be explained by local changes of the bog because a regional explanation for their absence has not been found.

The climate conditions during the studied period would induce a major biomass production facilitating the expansion of mesophytic communities that grow faster than conifers (Gil-Romera et al., 2014). Likewise, the low values of Pinus would not suggest a presence of pine forests in the vicinity. This observation is confirmed in other diagrams of the Iberian Atlantic coast (GarcíaAmorena et al., 2008; Moreno et al., 2011) and coincides with the absence of pine macroremains in nearby caves (Peña-Chocarro et al. 2005). Rubiales et al. (2008) suggest that deciduous taxa would have been favored over coniferous species because of the temperate and humid climate, creating a remarkable cover of flammable fuel necessary for fires.

It is important to keep in mind that fire linked to agricultural activities has had great influence on the configuration of the environment intensify continuously between the Bronze Age and the Roman period (Arias, 1999). The continuous decline in tree cover is associated with the presence of pastures and alternating burnings on the near slopes that favored the development of Ericaceae. Some parallelisms are found at Mediterranean sites. During the mid-Holocene, the vegetation around Stagno di Sa Curcurica (Sardinia, Italy) was characterized by dense Erica scoparia and E. arborea stands, which were favored by high fire activity (Beffa et al., 2015).

The intensification of fire activity in the last 1000 years in El Sertal represents an interesting point as regards the development of certain tree populations. That is the case of Fagus, it appears in the zone around $3000 \mathrm{cal} \mathrm{yr} \mathrm{BP}$ and reaches its maximum from around c. $1000 \mathrm{cal} \mathrm{yr} \mathrm{BP.} \mathrm{This} \mathrm{episode} \mathrm{is}$ evidenced in most of the sequences of the Iberian Peninsula (Muñoz-Sobrino et al. 2009). Fire could have helped to create the conditions necessary for Fagus expansion while total tree pollen percentages fell and heathland began to expand.

This article is protected by copyright. All rights reserved. 


\section{CONCLUSIONS}

The comparisons between the three sequences provide evidence that fire has been a key factor in the retreat of the forest and subsequently in the maintenance of open landscapes since the Neolithic. Over the past 7000 years, the intensity and chronology of fire events was unequal at the three sites studied, which can be interpreted as the result of asynchronous human activity in the high and low mountain areas and, at the same time, of the type of fuel involved in each zone.

The patterns of fires have varied significantly on a regional scale since the Neolithic period. In La Molina, the maximum values occurred between 5800 and 3500 cal years BP, whereas in El Cueto de la Avellanosa they were observed between 3600 and 1700 cal years BP. At El Sertal, the fire events occurred mainly during the past millennium, although open spaces are evident in the record from the very base of the sequence.

The phases of decline in organic matter, which could reflect more erosive periods, do not seem to be directly related to the rates of sedimentary charcoal accumulation. The catchment area at La Molina quantitatively favored the deposition of local charcoal as well as that from surrounding hillsides. At El Sertal and El Cueto de la Avellanosa, the peat bogs are located on hills and provide a much more local reflection of fire events.

At both El Sertal and El Cueto de la Avellanosa, the increase in Ericaceae around 3000 cal years BP is synchronous with the reduction in arboreal cover. At El Cueto de la Avellanosa, this landscape transformation coincides with an increase in sedimentary charcoals, defining a model of anthropic pressure intensification related to the use of fire.

Even though much of the Neolithic control of Cantabrian fires was basically human, we cannot rule out synergies with the climate and its influence in the processes of human adaptation to mountain areas. Two major climatic moments have been identified, in 4200 and 2800 cal years BP, which coincide with the transition to the Age of Metals (Bronze and Iron). The presence of human activity since the Neolithic period would have enhanced the effects of the drought cycles of the mid-late Holocene, increasing fire activity.

Forest fires induced by human activity can be identified from plant taxa that indicate fire and recurrent human presence at different historical moments. In Cantabria, the most important of these are Poaceae, Pteridium, Ericaceae and Plantago. The important presence of secondary communities of species such as Corylus should also be emphasized. The increase of Fagus in the last thousand years is another response to anthropic forest clearing. The study of the history of the vegetation in the Cantabrian Mountains reveals the direct relationship between the use of fire and the agro-livestock system, in particular cereal cultivation, from its origins.

\section{Acknowledgements}

This article was made possible by two Coordinated Project grants from Spain's Ministry of Economics and Competitiveness (MEC), "El uso del fuego y la conformación de los paisajes en la Montaña cantábrica y el Pirineo oriental: estudio comparado de su evolución histórica y tendencias actuales" (CSO2012-39680-C02-01) awarded to the Department of Geography, Urban studies and Land Planning, Universidad de Cantabria and "Geohistoria ambiental del fuego en el Holoceno. Patrones culturales y gestión territorial desde el inicio de la ganadería y la agricultura en la montaña Cantábrica y Pirineo "awarded to the Department of Geography, Universitat Autónoma de Barcelona (CSO2012-39680-C02-02). In addition, the project was funded by the Catalan government's Applied Geography program, "Grup de Geografia Aplicada" (AGAUR, Generalitat de Catalunya, 2014 SGR 1090). 
The authors wish to acknowledge the special research assistance provided by V. Castillo of the Universidad de Cantabria and multiple collaborators: Aaron Pérez-Haase, Almudena Merino, Marc Sánchez, Josep Manuel "Pepo" Rodríguez, Sandra Picart, Anna Franch, Salvador Beato, Eric Sobrevia and Elena Mur. We thank all of them for their help.

The authors appreciate the English language review by Elaine M. Lilly, Ph.D.

\section{REFERENCES}

AeMet. 2011. Atlas climático ibérico. Temperaturas de aire y precipitación. Ministerio de Medio Ambiente y Medio Rural y Marino-Instituto de Meteorologia de Portugal. http://www.aemet.es/documentos/es/conocermas/publicaciones/Atlas-climatologico/Atlas.pdf

Álvarez SG, Bal MC, Allée P, García-Amorena I, Rubiales JM. 2017. Holocene treeline history of a high-mountain landscape inferred from soil charcoal: The case of Sierra de Gredos (Iberian Central System, SW Europe). Quaternary International. DOI: 10.1016/j.quaint.2017.04.019

Aja Sánchez JR, Cisneros Cunchillos M, Ramírez Sádaba JL. 2008. Cantabria bajo el dominio de Roma: la organización del territorio. In Los cántabros en la antigüedad. La historia frente al mito. Aja JR, Cisneros JM, Ramírez JL. (ed). Ediciones de la Universidad de Cantabria: Santander; 133- 166.

Ali AA, Blarquez O, Girardin MP, Hély C, Tinquaut F, El Guellab A, Valsecchi V, Terrier A, Bremond L, Genries A, Gauthier S. 2012. Control of the multimillennial wildfire size in boreal North America by spring climatic conditions. PNAS 109 (51): 20966-20970. DOI: 10.1073/pnas.1203467109

Álvarez-Fernández E. 2015. Continuity of human-marine fauna interaction during the Holocene in Cantabrian Spain. Quaternary International 364: 188-195. DOI: 10.1016/j.quaint.2014.08.014

Arias P, Álvarez-Fernández E, Cubas M, Teira LC, Tapia J, Cueto M. 2013. Intervención arqueológica en el sistema kárstico de Arangas (Cabrales): Campaña de 2007. In Excavaciones arqueológicas en Asturias 2007-2012. Consejería de Cultura Principado de Asturias: Oviedo; 121-133. https://www.researchgate.net/publication/261213731_Intervenclon_arqueologica_en_el_sistema_ karstico_de_Arangas_Cabrales_Campana_de_2007

Arias $\mathrm{P}$, Armendariz A, Teira L. 2006. The megalithic complex in Cantabrian Spain. In Le mégalithisme atlantique: The Atlantic megaliths. Acts of the XIVth UISPP Congress, BAR International Series 1521 Rodríguez Casal A. (ed). Archaeopress: Oxford; 11-29

Arias P. 1999. Antes de los cántabros. Panorama del Neolítico y las edades de los metales en Cantabria. In I Encuentro de Historia de Cantabria. Universidad de Cantabria-Gobierno de Cantabria: Santander; 209-255.

Bal MC, Pèlachs A, Pérez-Obiol R, Julià R, Cunill R. 2011. Fire history and human activities during the last 3300 cal yr BP in Spain's Central Pyrenees: the case of the Estany de Burg. Palaeogeography, Palaeoclimatology, Palaeoecology 300: 179-190. DOI: 10.1016/j.palaeo.2010.12.023

Beffa G, Pedrotta T, Colombaroli D, Henne PD, van Leeuwen JFN, Su P, Kaltenrieder P, Adolf C, Vogel H, Pasta S, Anselmetti FS, Gobet E, Tinner W. 2015. Vegetation and fire history of coastal northeastern Sardinia (Italy) under changing Holocene climates and land use. Vegetation History and Archaeobotany. DOI: 10.1007/s00334-015-0548-5

Blaauw M. 2010. Methods and code for 'classical' age-modelling of radiocarbon sequences. Quaternary Geochronology 5: 512-518. DOI: 10.1016/j.quageo.2010.01.002

Blas Cortina MA de, Fernández Manzano J. 1992. Asturias y Cantabria en el primer milenio a.C. Complutum 2-3: 399-416. 
Bond G, Kromer B, Beer J, Muscheler R, Evans MN, Showers W, Hoffmann S, Lotti-Bond R, Hajdas I, Bonani G. 2001. Persistent solar influence on North Atlantic climate during the Holocene. Science 294: 2130. DOI: $10.1126 /$ science. 1065680

Burjachs F, Expósito I. 2015. Charcoal and Pollen Analysis: Examples of Holocene Fire Dynamics in Mediterranean Iberian Peninsula. Catena 135: 340-349. DOI: 10.1016/j.catena.2014.10.006

Carcaillet C, Bouvier M, Fréchette B, Larouche AC, Richard PJH., 2001. Comparison of pollen-slide and sieving methods in lacustrine charcoal analysis for local and regional fire history. The Holocene 11: 467-476. DOI: 10.1191/095968301678302904

Carcaillet C, Bergman I, Delorme S, Hornberg G, Zackrisson O. 2007. Long-term fire frequency not linked to prehistoric occupations in northern Swedish boreal forest. Ecology 88 (2): 465-477. DOI: 10.1890/0012-9658(2007)88[465:LFFNLT]2.0.CO;2

Carcaillet C, Hörnberg G, Zackrisson, O. 2012. Woody vegetation, fuel and fire track the melting of the Scandinavian ice-sheet before 9500 cal yr BP. Quaternary Research 78 (3): 540-548. DOI: 10.1016/j.yqres.2012.08.001

Carozza L, Galop D, Marembert F, Monna F. 2005. Quel statut pour les espaces de montagne durant l'age du Bronze. Regards croisés sur les approches société-environnement dans les Pyrénées occidentales. Documents d'Archéologie méridionale 28: 7-23.

Carracedo V, 2015. Incendios forestales y gestión del fuego en Cantabria. PhD Thesis, Universidad de Cantabria: Santander.

Carrion Y, Kaal J, López-Sáez JA, López-Merino L, Martínez Cortizas A. 2010. Holocene vegetation changes in NW Spain revealed by anthracological and palynological records from a colluvial soil. The Holocene 20 (1):1-14. DOI: 10.1177/0959683609348849

Ceballos Cuerno C. 2001. Arozas y Ferrones. Las ferrerías de Cantabria en el antiguo régimen. Universidad de Cantabria: Santander.

Cisneros Cunchillos M, Marco Simón F, Pina Polo F, Ramírez Sádaba JL. 2008. La situación de los pueblos cántabros antes de la conquista romana. In Los cántabros en la antigüedad. La historia frente al mito Aja JR, Cisneros JM, Ramírez JL. (ed). Ediciones de la Universidad de Cantabria: Santander: 49-100.

Clark JS. 1988. Particle motion and the theory of charcoal analysis: source area, transport, deposition and sampling. Quaternary Research 30: 67-80. DOI: 10.1016/0033-5894(88)90088-9

Colombaroli D, Vannière B, Chapron E, Magny M, Tinner W. 2008. Fire-vegetation interactions during the Mesolithic-Neolithic transition at Lago dell'Accesa, Tuscany, Italy. The Holocene 18: 679692. DOI: $10.1177 / 0959683608091779$

Conedera M, Tinner W, Nef, C, Meurer M, Dickens AF, Krebs P. 2009. Reconstructing past fire regimes: methods, applications, and relevance to fire management and conservation. Quaternary Science Reviews 28 (5): 555-576. DOI: 10.1016/j.quascirev.2008.11.005

Cubas M, Altuna J, Álvarez Fernández E, Armendáriz Á, Fano MA, López Dóriga I, Mariezkurrena K, Tapia J Teira LC, Arias P. 2016. Re-evaluating the Neolithic: the impact and the consolidation of farming practices in the cantabrian region (Northern Spain). Journal of World Prehistory 29: 79-116. DOI: 10.1007/s10963-016-9091-2

Cunill R, Soriano JM, Bal MC, Pèlachs A, Pérez-Obiol R. 2012. Holocene treeline changes on the south slope of the Pyrenees: a pedoanthracological analysis. Vegetation History and Archaeobotny 21 (45): 373-384. DOI: 10.1007/s00334-011-0342-y 
Dean WE. 1974. Determination of carbonate and organic matter in calcareous sediments and sedimentary rocks by loss on ignition: Comparison with other methods. Journal of Sedimentary Petrology 44: 242-248. DOI: 10.1306/74D729D2-2B21-11D7-8648000102C1865D

Fano, MA, Gutiérrez-Zugasti I, Álvarez-Fernández E, Fernández R. 2013. Late Glacial and postglacial use of marine resources in the Bay of Biskay, North Spain. In Shell energy: Mollusc shells as coastal resources Bailey GN, Hardy K, Camara A. (eds). Oxbow Books: Oxford; 155-166.

Feurdean A, Spessa A, Magyari EK, Willis KJ, Veres D, Hickler T. 2012. Trends in biomass burning in the Carpathian region over the last 15,000 years. Quaternary Science Reviews 45: 111-125. DOI: 10.1016/j.quascirev.2012.04.001

Finsinger W, Kelly R, Fevre J, Magyari EK. 2014. A guide to screening charcoal peaks in macrocharcoal-area records for fire-episode reconstructions. The Holocene 24 (8): 1002-1008. DOI: $10.1177 / 0959683614534737$

Galop D, Carozza L, Marembert F, Bal MC. 2007. Activités agropastorales et climat durant l'Âge du Bronze dans les Pyrénées: l'état de la question à la lumière des données environnemental es et archéologiques. In Environnements et cultures à l'âge du Bronze en Europe occidentale Richard $\mathrm{H}$, Magny M, Mordant C. (eds). Documents préhistoriques 21, Comité des Travaux Historiques et Scientifiques: Paris; 07-119.

García-Amorena I, Morla C, Rubiales JM, Gómez-Manzaneque F. 2008. Taxonomic composition of the Holocene forests or the northern coast of Spain, as determined from their macroremains. The Holocene 18: 819-829. DOI: 10.1177/0959683608089218

Gassiot E, Rordríguez Antón D, Pèlachs A, Pérez-Obiol R, Julià R, Bal MC, Mazzucco N. 2014. La alta montaña durante la Prehistoria: 10 años de investigación en el Pirineo catalán occidental. Trabajos de Prehistoria 71 (2): 261-281. DOI: 10.3989/tp.2014.12134

Gil-Romera G, González-Sampériz P, Lasheras-Álvarez L, Sevilla-Callejo M, Moreno A, Valero-Garcés B, López-Merino L, Carrión JS, Pérez-Sanz A, Aranbarri J, García-Prieto Fronce E. 2014. Biomassmodulated fire dynamics during the Last Glacialelnterglacial Transition at the Central Pyrenees (Spain). Palaeogeography, Palaeoclimatology, Palaeoecology 402: 113-124. DOI: 10.1016/j.palaeo.2014.03.015

González Morales M, Straus LG, Díez Castillo A, Ruiz Cobo, J. 2004. Postglacial coast \& inland: the Epipaleolithic-Mesolithic-Neolithic transitions in the vasco-cantabrian region. Munibe 56: 61-78.

González Morales M, Estévez J. 2004. De los pioneros a los albores del siglo XXI. Más de un siglo de investigación sobre el Paleolítico Cantábrico. Kobie 8: 29-50.

González-Pellejero R, Allende F, López-Sáez JA, Frochoso-Sánchez M, Alba- Sánchez F, Abel-Schaad D. 2014. Dinámicas naturales y antrópicas en los paisajes vegetales de los valles internos de Cantabria occidental (Norte de España). Boletín de la Asociación de Geógrafos Españoles 65: 139-165

Grimm EC. 1991. TILIA and Tilia. Graph and TGView. Illinois State Museum, Research and Collections Center: Springfield

Heiri O, Lotter AF and Lemcke G. 2001. Loss on ignition as a method for estimating organic and carbonate content in sediments: Reproducibility and comparability of results. Journal of Paleolimnology 25: 101-110. DOI: 10.1023/A:1008119611481

Higuera PE, Brubaker LB, Anderson PM, Hu FS, Brown TA. 2009. Vegetation mediated the impacts of postglacial climate change on fi re regimes in the south- central Brooks Range, Alaska. Ecological Monographs 79: 201-219. http://onlinelibrary.wiley.com/doi/10.1890/07-2019.1/pdf 
Higuera PE, Gavin DG, Bartlein PJ, Hallett DJ. 2011. Peak detection in sediment-charcoal records: impacts of alternative data analysis methods on fire-history interpretations. International Journal of Wildland Fire 19: 996-1014. DOI: 10.1071/WF09134

Higuera PE, Peters ME, Brubaker LB, Gavin DG. 2007. Understanding the origin and analysis of sediment-charcoal records with a simulation model. Quaternary Science Reviews 26: 1790-1809. DOI: 10.1016/j.quascirev.2007.03.010

Higuera PE, Sprugel DG, Brubaker LB, 2005. Reconstructing fire regimes with charcoal from smallhollow sediments: a calibration with tree-ring records of fire. The Holocene 15: 238-251. DOI: 10.1191/0959683605hl789rp

Jalut G, Turu-Michels V, Deboubat JJ, Otto T, Ezquerra J, Fontugne M, Belet JM, Bonnet L, García-deCelis A, Redondo-Vega JM, Vidal-Romaní JR, Santos L. 2010. Paleoenvironmental studies in NW Iberia (Cantabrian range) Vegetation history and synthetic approach of the Last Deglaciation phases in western Mediterranean. Palaeogeography, Palaeoclimatology, Palaeoecology 297(2): 330-350. DOI: 10.1016/j.palaeo.2010.08.012

López-Merino L, Martínez-Cortizas A, López-Sáez JA. 2010. Early agriculture and palaeoenvironmental history in the North of the Iberian Peninsula: a multi-proxy analysis of the Monte Areo mire (Asturias, Spain). Journal of Archaeological Science 37: 1978-1988. DOI: 10.1016/j.jas.2010.03.003

López Sáez JA, Vargas G, Ruiz Fernández J, Blarquez O, Alba-Sánchez F, Oliva M, Pérez-Díaz S, RoblesLópez S, Abel-Schaad D. 2017. Paleofire Dynamics in Central Spain During the Late Holocene: the Role of Climatic and Anthropogenic Forcing. Land Degradation \& Development. DOI: 10.1002/ldr.2751.

Mantecón Callejo L. 2000. La minería romana en Cantabria. Nivel Cero 8: 37-58.

Mariscal Alvarez B. 1983. Estudio de la turbera del Cueto de la Avellanosa, Poblaciones (Cantabria). VI Reunión del Grupo Español de trabajo del Cuaternario. Cuaderno do Laboratorio Xeoloxico de Laxe. Universidade da Coruña: Coruña; 205-226

Mariscal Alvarez B. 1986. Análisis polínico de la turbera del Pico Sertal, de la Sierra de Peña Labra. Reconstrucción de la paleoflora y de la paleoclimatología durante el Holoceno de la zona oriental de la cordillera cantábrica.In Proceedings of the Symposium on Climatic fluctuations during the Quaternary in the Western Mediterranean Regions López-Vera F. (ed). Universidad Autónoma de Madrid: Madrid; 205-220

Marlon J, Bartlein PJ, Whitlock C. 2006. Fire-fuel-climate linkages in the northwestern USA during the Holocene. The Holocene 16: 1059-1071. DOI: 10.1177/0959683606069396

Mercuri AM. 2014. Genesis and evolution of the cultural landscape in central Mediterranean: The "where, when and how" through the palynological approach. Landscape Ecology 29: 1799-1810

Mercuri AM, Sadori L. 2014 Mediterranean culture and climatic change: past patterns and future trends. In: Goffredo S, Dubinsky Z (eds) The Mediterranean sea: its history and present challenges. Springer, Dordrecht: 507-527

Moore PD, Webb JA, Collinson ME. 1991. Pollen Analysis. Blackwell: Oxford.

Moreno A, Lopez-Merino L, Leira M, Marco-Barba J, Gonzalez-Samperiz P, Valero-Garces BL, LopezSaez JA, Santos L, Mata P, Ito E. 2011. Revealing the last 13,500 years of environmental history from the multiproxy record of a mountain lake (Lago Enol, northern Iberian Peninsula). Journal of Paleolimnology 46: 327-349. DOI: 10.1007/s10933-009-9387-7

Moure Romanillo A, 1995. Patrimonio arqueológico y patrimonio etnográfico. In De la Montaña a Cantabria Moure Romanillo and Suárez Cortina (eds.). Universidad de Cantabria: Santander; 73-93. 
Muñoz-Sobrino C, Ramil-Rego P, Gómez-Orellana L, Ferreiro-da-Costa J, Díaz-Varela RA. 2009. Climatic and human effects on the post-glacial dynamics of Fagus sylvatica L. in NW Iberia. Plant Ecology 203 (2): 317-340. DOI: 10.1007/s11258-008-9552-5

Ohlson M, Tryterud E. 2000. Interpretation of the charcoal record in forest soils: forest fires and their production and deposition of macroscopic charcoal. The Holocene 10: 519-525. DOI: 10.1191/095968300667442551

Ontañón R. 1995. El Neolítico Final y el Calcolítico en Cantabria. Cuadernos de Prehistoria Arqueología 6: 81-104.

Ontañon R. 2003. Caminos hacia la complejidad: el Calcolítico en la región cantábrica. Universidad de Cantabria: Santander.

Ortega J. 1987. La Cantabria rural: sobre "La Montaña". Universidad de Cantabria: Santander.

Pèlachs A, Julià R, Pérez-Obiol R, Soriano JM, Bal MC, Cunill R, Catalan J. 2011. Potential influence of bond events on mid-Holocene climate and vegetation in southern Pyrenees as assessed from Burg lake LOI and pollen records. The Holocene 21 (1): 95-104. DOI: 10.1177/0959683610386820

Peña-Chocarro L, Zapata L, Iriarte MJ, González Morales M, Straus LG. 2005. The oldest agriculture in northern Atlantic Spain: new evidence from El Mirón Cave (Ramales de la Victoria, Cantabria. Journal of Archaeological Science 32 (4): 579-587. DOI: 10.1016/j.jas.2004.12.001

Peralta Labrador E. 2000. Los cántabros antes de Roma. Real Academia de Historia: Madrid.

Pérez-Obiol R, García-Codron JC, Pèlachs A, Pérez-Haase A, Soriano JM. 2016. Landscape dynamics and fire activity since $6740 \mathrm{cal}$ yr BP in the Cantabrian region (La Molina peat bog, Puente Viesgo, Spain). Quaternary Science Reviews 135 (1): 65-78. DOI: 10.1016/j.quascirev.2016.01.021

Power MJ, Marlon J, Ortiz N, Bartlein PJ, Harrison SP, Mayle FE, Ballouche A, Bradshaw R, Carcaillet C, Cordova C, Mooney S, Moreno P, Prentice IC, Thonicke K, Tinner W, Whitlock C, Zhang Y, Zhao Y, Anderson RS, Beer R, Behling H, Briles C, Brown KJ, Brunelle A, Bush M, Camill P, Chu GQ, Clark J, Colombaroli D, Connor S, Daniels M, Daniau AL, Dodson J, Doughty E, Edwards ME, Fisinger W, Foster D, Frechette J, Gaillard M- J, Gil - Romera G, Gavin DG, Gobet E, Haberle S, Hallett DJ, Higuera P, Hope G, Horn S, Impagliazzo S, Inou e J, Kaltenrieder P, Kennedy L, Kong ZC, Larsen C, Long CJ, Lynch J, Lynch B, McGlone M, Meeks S, Mensing S, Meyer G, Minckley T, Mohr J, Nelson D, New J, Newnham R, Noti R, Oswald W, Pierce J, Richard PJH, Row e C., Sanchez Goñi M.F, Shuman BJ, Takahara H, Toney J, Turney C, Umbanhowar C, Vandergoes M, Vanniere B, Vescovi E, Walsh M, Wang X, Williams N, Wilmshurst J, Zhang JH. 2008. Changes in fire regimes since the Last Glacial Maximum: an assessment based on a global synthesis and analysis of charcoal data. Climate Dynamics 30: 887 - 987. DOI: 10.1007/s00382-007-0334-x

R Core Team, 2015. R: a Language and Environment for Statistical Computing R. Foundation for Statistical Computing: Vienna.

Reille M. 1992. Pollen et spores d'Europe et d'Afrique du Nord. Laboratoire de Botanique Historique et Palynologie. Université d'Aix-Marseille III: Marseille.

Reille M. 1998. Pollen et spores d'Europe et d'Afrique du Nord Supplément 2. Laboratoire de Botanique Historique et Palynologie. Université d'Aix-Marseille III: Marseille.

Reimer PJ, Bard E, Bayliss A, Beck JW, Blackwell PG, Bronk Ramsey C, Buck CE, Cheng H, Edwards RL, Friedrich M, Grootes PM, Guilderson TP, Haflidason H, Hajdas I, Hatte C, Heato, TJ, Hoffmann DL, Hogg AG, Hughen KA, Kaiser KF, Kromer B, Manning SW, Niu M, Reimer RW, Richards DA, Scott EM, Southon JR, Staff RA, Turney CSM, van der Plicht J. 2013. IntCal13 and Marine13 radiocarbon age calibration curves 0-50,000 years cal BP. Radiocarbon 55 (4): 1869-1887. DOI: 10.2458/azu_js_rc.55.16947 
Rius D, Vannière B, Galop D. 2009. Fire frequency and landscape management in the north-western Pyrenean piedmont (France) since the early Neolithic (8000 cal. BP). The Holocene 19 (6): 847-859. DOI: $10.1177 / 0959683609105299$

Rius D, Vannière B, Galop D. Richard H. 2011. Holocene fire regime changes from multiple-site sedimentary charcoal analyses in the Lourdes basin (Pyrenees, France). Quaternary Science Reviews 30: 1696-1709. DOI: 10.1016/j.quascirev.2011.03.014

Rius D, Galop D, Doyen E, Millet L, Vannière B. 2014. Biomass burning response to high-amplitude climate and vegetation changes in Southwestern France from the Last Glacial to the early Holocene. Vegetation history and archaeobotany 23(6): 729-742. DOI: 10.1007/s00334-013-0422-2

Rubiales JM, García-Amorena I, García-Álvarez S, Gómez-Manzaneque F. 2008. The Late Holocene extinction of Pinus sylvestris in the western Cantabrian Range (Spain). Journal of Biogeography 35: 1840-1850. DOI: 10.1111/j.1365-2699.2008.01925.x.

Ruiz Alonso M, Pérez Díaz S, López Sáez JA, Zapata L. 2011. Carbón y polen. Un ejemplo de comparación de dos registros arqueobotánicos en Álava durante la Edad del Bronce: Peña Parda Kobie. Serie Paleoantropología 30: 63 - 72.

Sadori L, Masi A, Ricotta C. 2015. Climate-driven past fires in central Sicily. Plant Biosystems 149 DOI: 10.1080/11263504.2014.992996

Thevenon F, Bard E, Williamson D, Beaufort L. 2004. A biomass burning record from the West Equatorial Pacific over the last $360 \mathrm{ky}$ : methodological, climatic and anthropic implications. Palaeogeography, Palaeoclimatology, Palaeoecology 213: 83-99. DOI: 10.1016/j.palaeo.2004.07.003

Thevenon F, Williamson D, Vincens A, Taieb M, Merdaci O, Decobert M, Buchet G. 2003. A lateHolocene charcoal record from Lake Masoko, SW Tanzania: climatic and anthropologic implications. The Holocene 13 (5): 785-792. DOI: 10.1191/0959683603hl665rr

Vannière $B$, Colombaroli D, Chapron E, Leoux A, Tinner W, Magny M. 2008. Climate versus humandriven fire regimes in Mediterranean landscapes: The Holocene record of Lago dell'Accesa (Tuscany, Italy). Quaternary Science Reviews 27: 1181-1196. DOI: 10.1016/j.quascirev.2008.02.011

Vannière B, Power MJ, Roberts N, Tinner W, Carrión J. 2011. Circum-Mediterranean fire activity and climate changes during the mid-Holocene environmental transition (8500 e $2500 \mathrm{cal}$. BP). The Holocene 21: 53-73. DOI: 10.1177/0959683610384164

Vannière $B$, Blarquez $O$, Rius $D$, Doyen $E$, Brücher $T$, Colombaroli $D$, Connor $S$, Feurdean $A$, Hickler $T$, Kaltenrieder P, Lemmen C, Leys B, Masa C Olofsson J. 2016. 7000-year human legacy of elevationdependent European fire regimes. Quaternary Science Reviews 132: 206-212. DOI: 10.1016/j.quascirev.2015.11.012

Whitlock C, Larsen C. 2001. Charcoal as a fire proxy. In Tracking Environmental Change Using Lake Sediments, Terrestrial, Algal, and Siliceous Indicators, vol. 3 Smol JP, Birks HJB, Last WM. (eds). Kluwer Academic Publishers: Dordrecht; 75-97.

This article is protected by copyright. All rights reserved. 
Table 1. Cultural stages and chronology in the Cantabrian Region

\begin{tabular}{|c|c|c|c|}
\hline Cultural stages & $\begin{array}{l}\text { Chronology } \\
\text { (cal ka BP) }\end{array}$ & $\begin{array}{l}\text { Main characteristics of human } \\
\text { presence in the territory }\end{array}$ & References \\
\hline 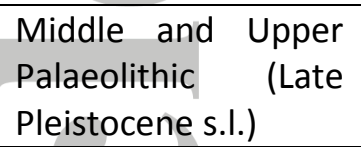 & $>10$ & $\begin{array}{l}\text { Groups of hunter-gatherers, } \\
\text { mainly in the low valleys and } \\
\text { coastal area. }\end{array}$ & $\begin{array}{l}\text { González Morales } \\
\text { et al., } 2004\end{array}$ \\
\hline $\begin{array}{l}\text { Epipalaeolithic- } \\
\text { Mesolithic }\end{array}$ & 10 to 7 & $\begin{array}{l}\text { Hunter-gatherers mainly on the } \\
\text { coast, although the mountain } \\
\text { area is frequented. }\end{array}$ & $\begin{array}{l}\text { Fano et al., } 2013 \\
\text { Álvarez Fernández, } \\
2015\end{array}$ \\
\hline $\mathrm{Nec}$ & 7 to 5.6 & $\begin{array}{l}\text { The emergence of grazing in } \\
\text { the Neolithic period radically } \\
\text { changed this pattern of } \\
\text { occupation of the territory by } \\
\text { encouraging the exploitation of } \\
\text { all mid-mountain areas. }\end{array}$ & $\begin{array}{l}\text { González Morales } \\
\text { et al., } 2004 \\
\text { Cubas et al., } 2016 \\
\text { Peña Chocarro et } \\
\text { al., } 2005 \\
\text { Arias et al., } 2013\end{array}$ \\
\hline Cha & 5.6 to 3.8 & $\begin{array}{l}\text { Intensification of the producer } \\
\text { economy in mid-mountain } \\
\text { areas. First settlements. }\end{array}$ & $\begin{array}{l}\text { Arias et al., } 2006 \\
\text { Ontañón, } 1995 \text { and } \\
2003\end{array}$ \\
\hline Bron & 3.8 to 2.7 & $\begin{array}{l}\text { Strong growth of agricultural } \\
\text { and livestock farming activities. } \\
\text { Occupation of new areas. }\end{array}$ & $\begin{array}{l}\text { Blas and Fernández, } \\
1992 \\
\text { Arias, } 1999\end{array}$ \\
\hline Iron & 2.7 to 2.1 & $\begin{array}{l}\text { Fortified settlements and large } \\
\text { deforested areas at the } \\
\text { summits of mid-mountain } \\
\text { areas. } \\
\text { Mining and metallurgy of iron } \\
\text { in the coastal area }\end{array}$ & $\begin{array}{l}\text { Peralta, } 2000 \\
\text { Cisneros et al., } \\
2008 \\
\text { Mantecón, } 2000\end{array}$ \\
\hline $\begin{array}{l}\text { and Early } \\
\text { ges }\end{array}$ & 2.1 to 1.1 & $\begin{array}{l}\text { Small towns, agriculture, and } \\
\text { active metallurgy in coastal } \\
\text { areas. Livestock and a few } \\
\text { fortified settlements in } \\
\text { mountain areas. }\end{array}$ & $\begin{array}{l}\text { Mantecón, } 2000 \\
\text { Aja et al., } 2008\end{array}$ \\
\hline $\begin{array}{l}\text { Middle Ages to } \\
\text { Precontemporary }\end{array}$ & 1.1 to 0.15 & $\begin{array}{l}\text { Increasing agricultural and } \\
\text { livestock pressure. The } \\
\text { productive space of the villages } \\
\text { covers the whole territory. } \\
\text { Overexploitation of forests to } \\
\text { meet the demands of the naval, } \\
\text { steel and coal industries. }\end{array}$ & $\begin{array}{l}\text { Ortega, } 1984 \\
\text { Ceballos, } 2001\end{array}$ \\
\hline
\end{tabular}

This article is protected by copyright. All rights reserved. 
Table 2: Radiocarbon data for the peat bog cores analyzed.

A. La Molina

\begin{tabular}{|c|c|c|c|c|c|}
\hline $\begin{array}{c}\text { Laboratory } \\
\text { code }\end{array}$ & $\begin{array}{c}\text { Sample } \\
\text { depth } \\
\text { (cm) }\end{array}$ & Material dated & $\begin{array}{c}\mathbf{1 3 C / 1 2 C} \\
\mathbf{( 0 / 0 0 )}\end{array}$ & $\begin{array}{c}\text { Conventional } \\
\text { radiocarbon } \\
\text { age }\end{array}$ & $\begin{array}{c}\text { Age used for } \\
\text { chronological } \\
\text { model } \\
\text { [cal yr BP] }\end{array}$ \\
\hline $\begin{array}{c}\text { Documentary } \\
\text { data }\end{array}$ & 14 & $\begin{array}{c}\text { Pinus/Eucalyptus } \\
\text { plantations }\end{array}$ & & & 0 (1950 AD) \\
\hline Beta-371859 & 40 & Peat & -27.5 & $650 \pm 30$ & 580 \\
\hline Beta-385973 & 68 & Peat & -27.3 & $3340 \pm 30$ & 3575 \\
\hline Beta-371860 & 113 & Peat & -25.9 & $3480 \pm 30$ & 3800 \\
\hline Beta-371861 & 186 & Peat & -26.6 & $4130 \pm 30$ & 4760 \\
\hline Beta-360118 & 260 & Peat & -27.7 & $5910 \pm 30$ & 6740 \\
\hline
\end{tabular}

Source: Pérez-Obiol et al. (2016) Quaternary Science Review 135: 65-78.

B. El Sertal

\begin{tabular}{|c|c|c|c|c|c|}
\hline $\begin{array}{c}\text { Laboratory } \\
\text { code }\end{array}$ & $\begin{array}{c}\text { Sample } \\
\text { depth }(\mathbf{c m})\end{array}$ & Material dated & $\begin{array}{c}\mathbf{1 3 C / 1 2 C} \\
\mathbf{( 0 / 0 0 )}\end{array}$ & $\begin{array}{c}\text { Conventional } \\
\text { radiocarbon } \\
\text { age }\end{array}$ & $\begin{array}{c}\text { Age used for } \\
\text { chronological } \\
\text { model } \\
\text { [cal yr BP] }\end{array}$ \\
\hline Beta-424743 & 17.5 & Plant material & -29.3 & $1520 \pm 30$ & 1404 \\
\hline Beta-448487 & 26.9 & Organic sediment & -28.9 & $2590 \pm 30$ & 2741 \\
\hline Beta-371862 & 38 & Organic sediment & -28.3 & $4520 \pm 30$ & 5158 \\
\hline
\end{tabular}

C. El Cueto de la Avellanosa

\begin{tabular}{|c|c|c|c|c|c|}
\hline $\begin{array}{c}\text { Laboratory } \\
\text { code }\end{array}$ & $\begin{array}{c}\text { Sample } \\
\text { depth }(\mathbf{c m})\end{array}$ & Material dated & $\begin{array}{c}\mathbf{1 3 C} / \mathbf{1 2 C} \\
\mathbf{( 0 / 0 0 )}\end{array}$ & $\begin{array}{c}\text { Conventional } \\
\text { radiocarbon } \\
\text { age }\end{array}$ & $\begin{array}{c}\text { Age used for } \\
\text { chronological } \\
\text { model } \\
\text { [cal yr BP] }\end{array}$ \\
\hline Beta-410651 & 56 & Plant material & -24.7 & $1410 \pm 30$ & 1317 \\
\hline Beta-410652 & 196 & Plant material & -28.1 & $3260 \pm 30$ & 3489 \\
\hline Beta-371855 & 399 & Organic sediment & -28.2 & $6120 \pm 40$ & 7005 \\
\hline
\end{tabular}

This article is protected by copyright. All rights reserved. 


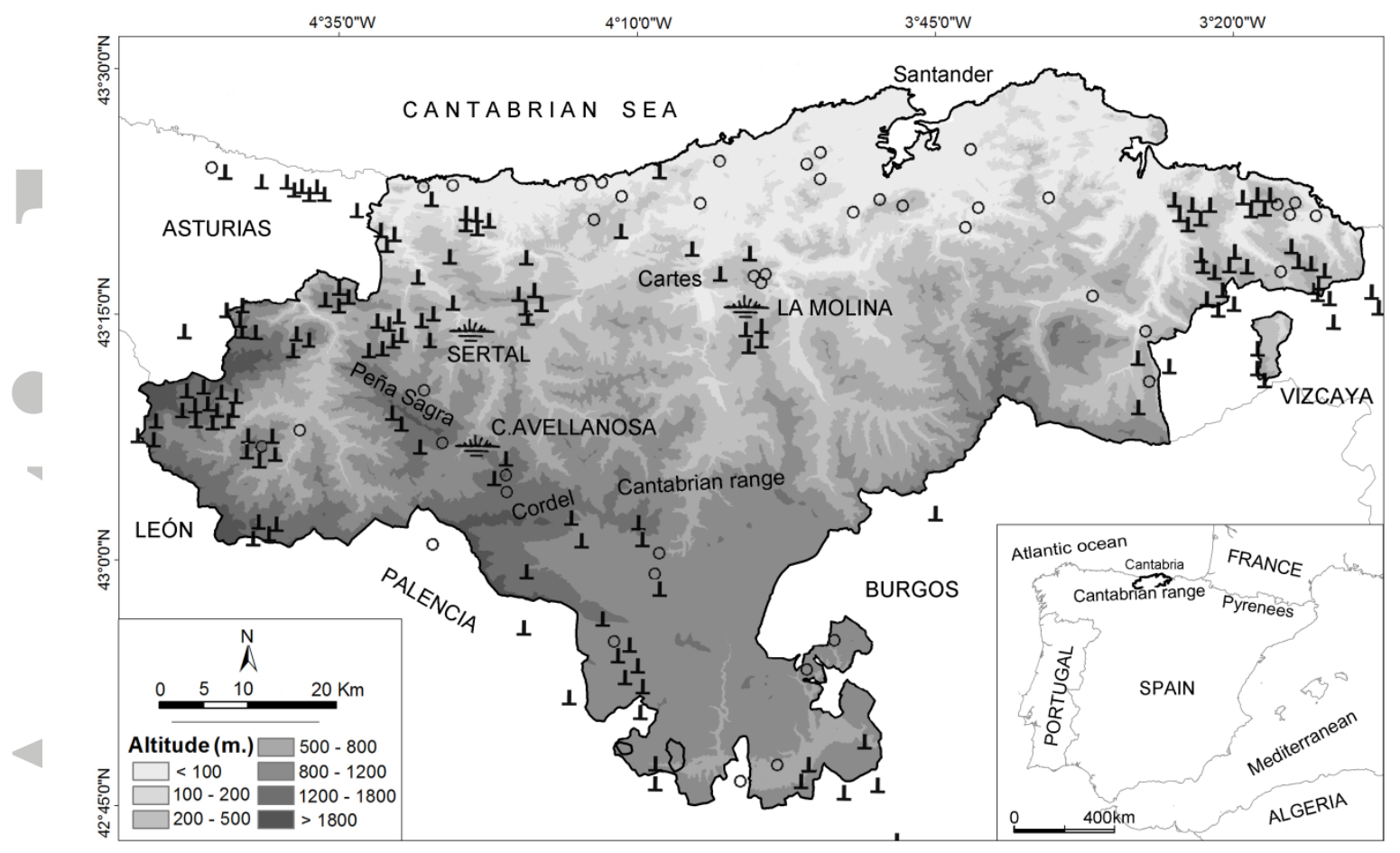

Fig. 1. Location of the peat bogs and of the main archaeological remains from the recent prehistory of Cantabria (inverted $\mathrm{T}=$ megaliths; Circle $=$ Chalcolithic to Bronze Age sites). 


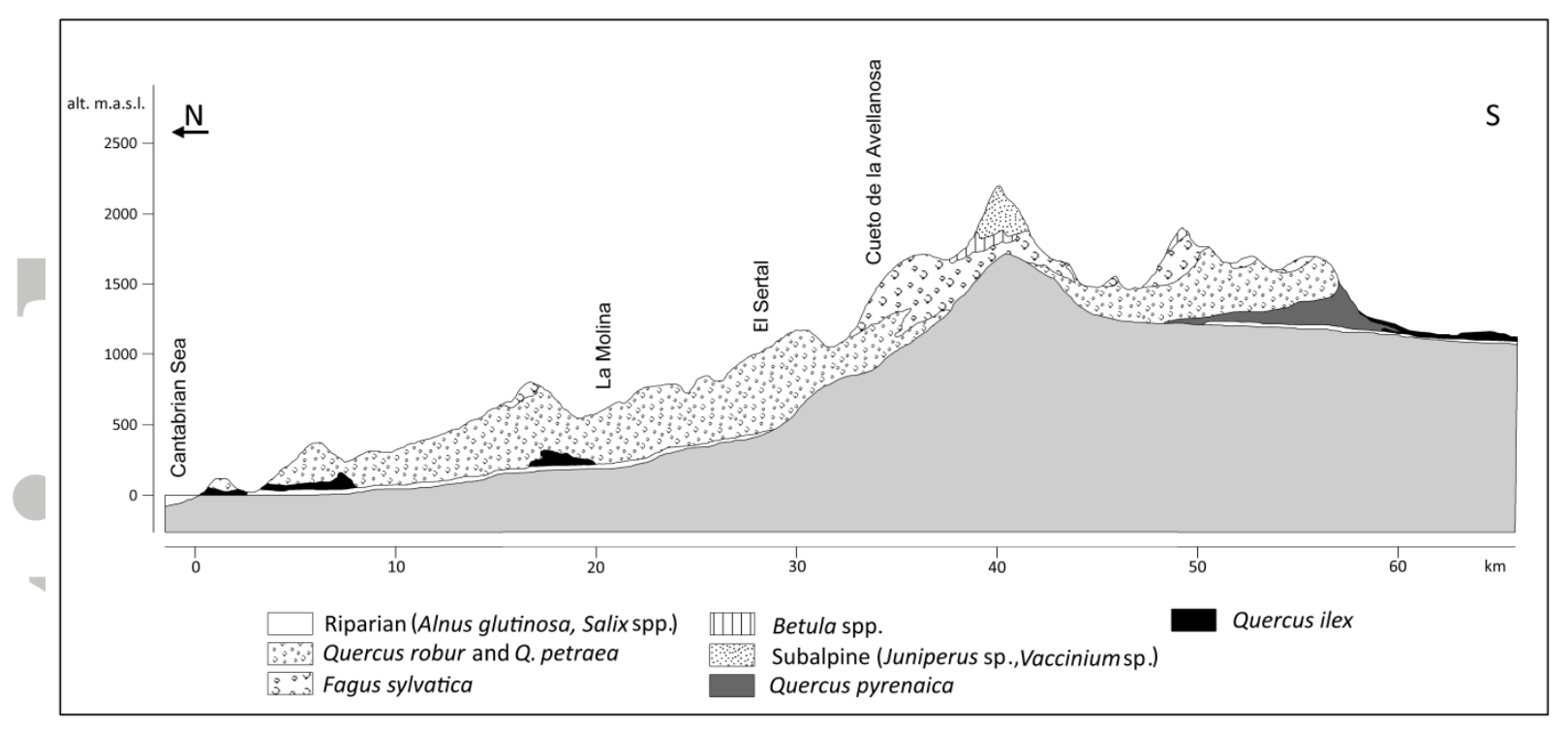

Fig 2. Altitudinal zonation of the Cantabrian mountains and location of the peat bogs studied.
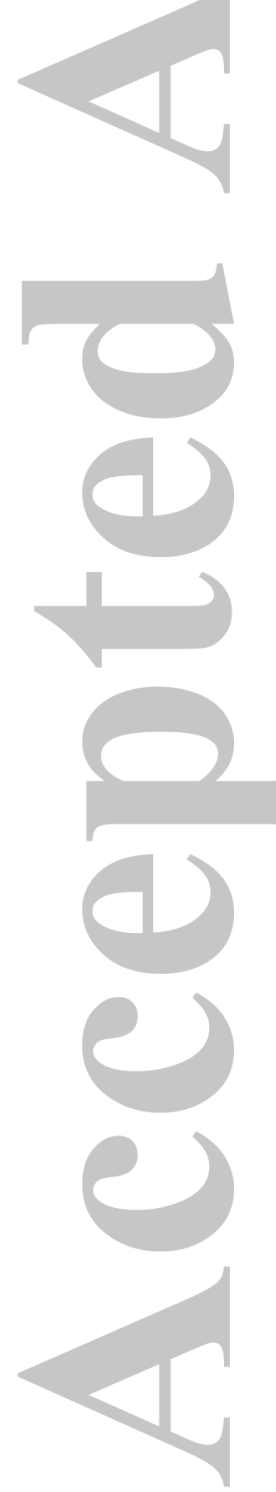

This article is protected by copyright. All rights reserved. 


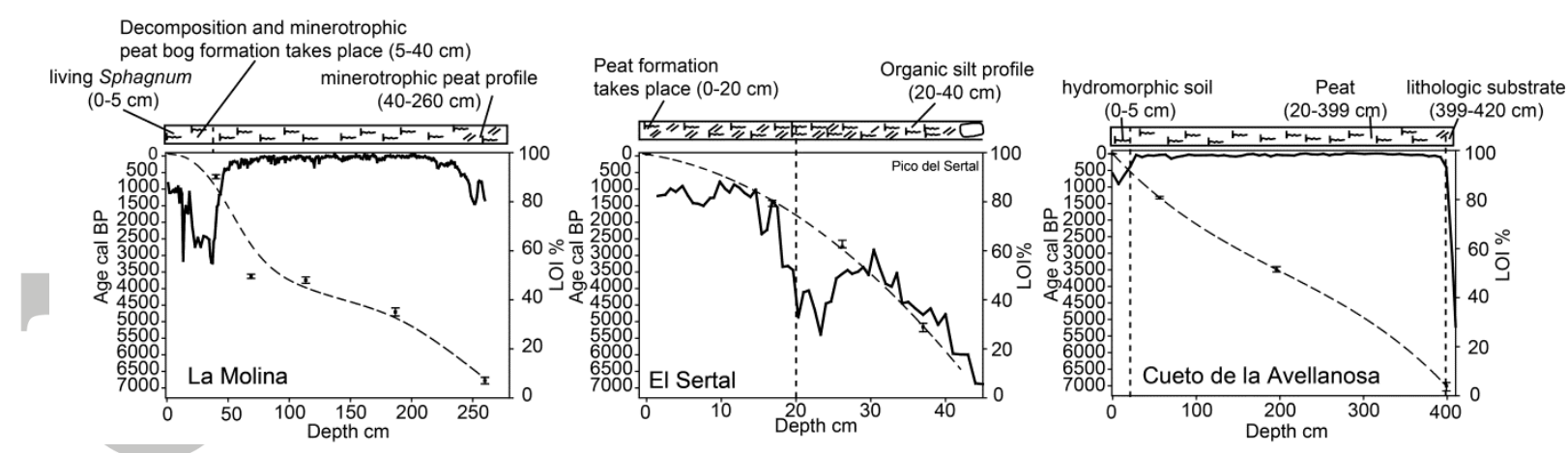

Fig. 3. Age-depth models with location of the radiocarbon samples, values for organic matter, and description of sediment. The main lithology of La Molina is peat. At El Sertal, there are three main sediment units (peat, organic silt, and silt). At Cueto de la Avellanosa, the peat lies above the lithological substrate (comprising Permian lutites and sandstones with large blocks of siliceous conglomerates of the same age). NOTE: 14C dates for these sequences are shown in Table 2.
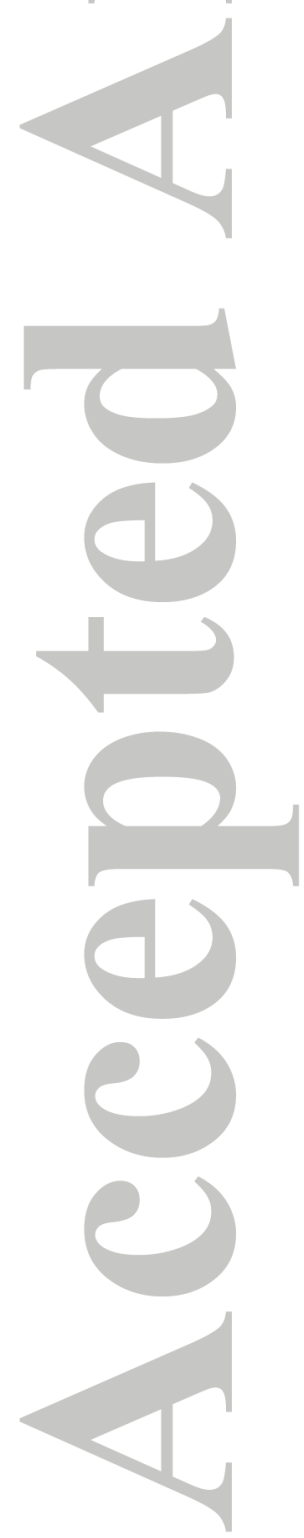


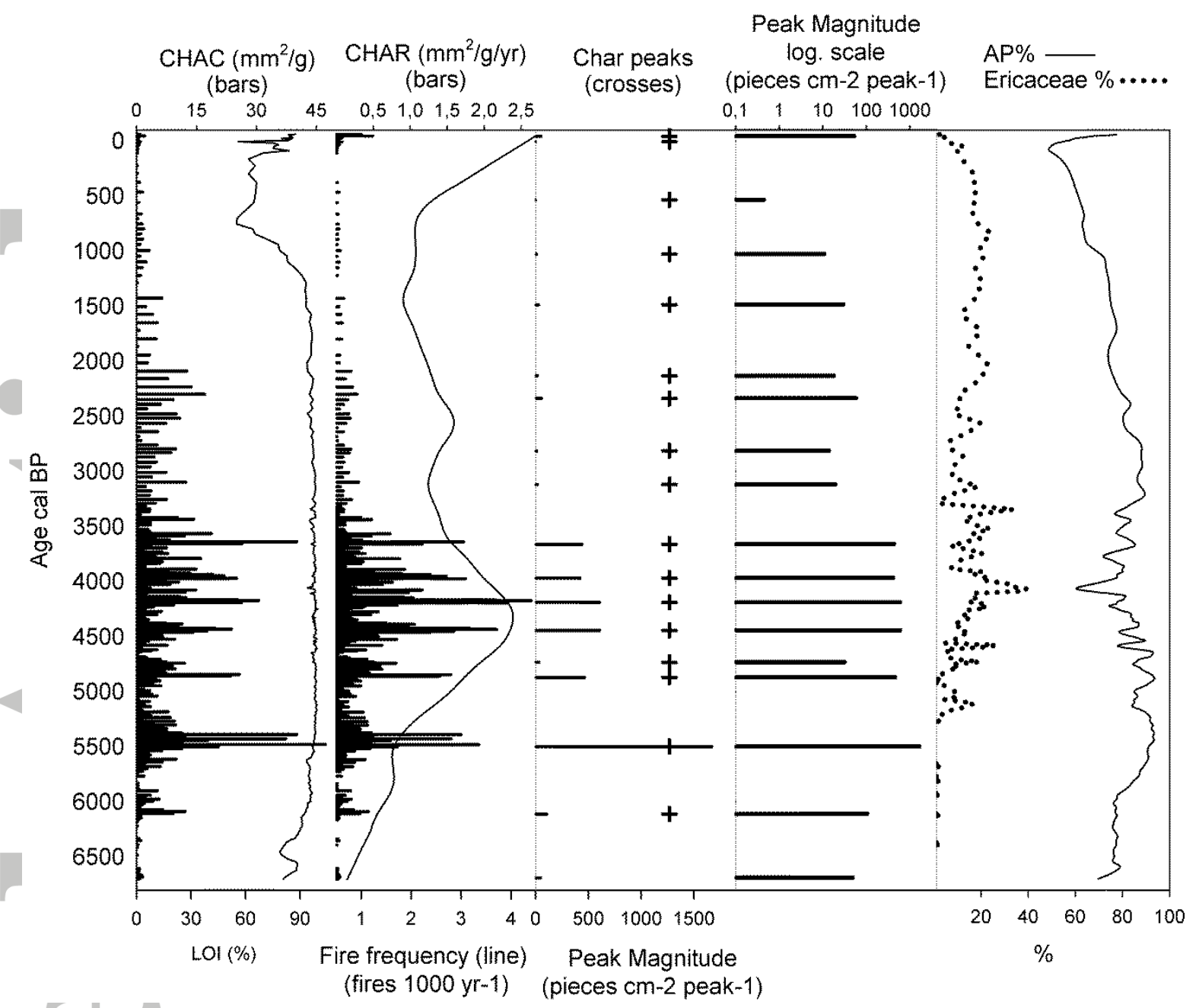

Fig. 4. CHAC, LOI, CHAR, Fire frequency, CHAR peaks, Peak magnitude (1000-year window) and changes in arboreal and Ericaceae pollen at La Molina. The most intense fires coincide with the highest arboreal pollen values. Significant fire events were identified from the very base to the end of the sequence; the highest frequency and intensity occurred between 5800 and 3500 cal years BP, when there was also a dense forest cover. 


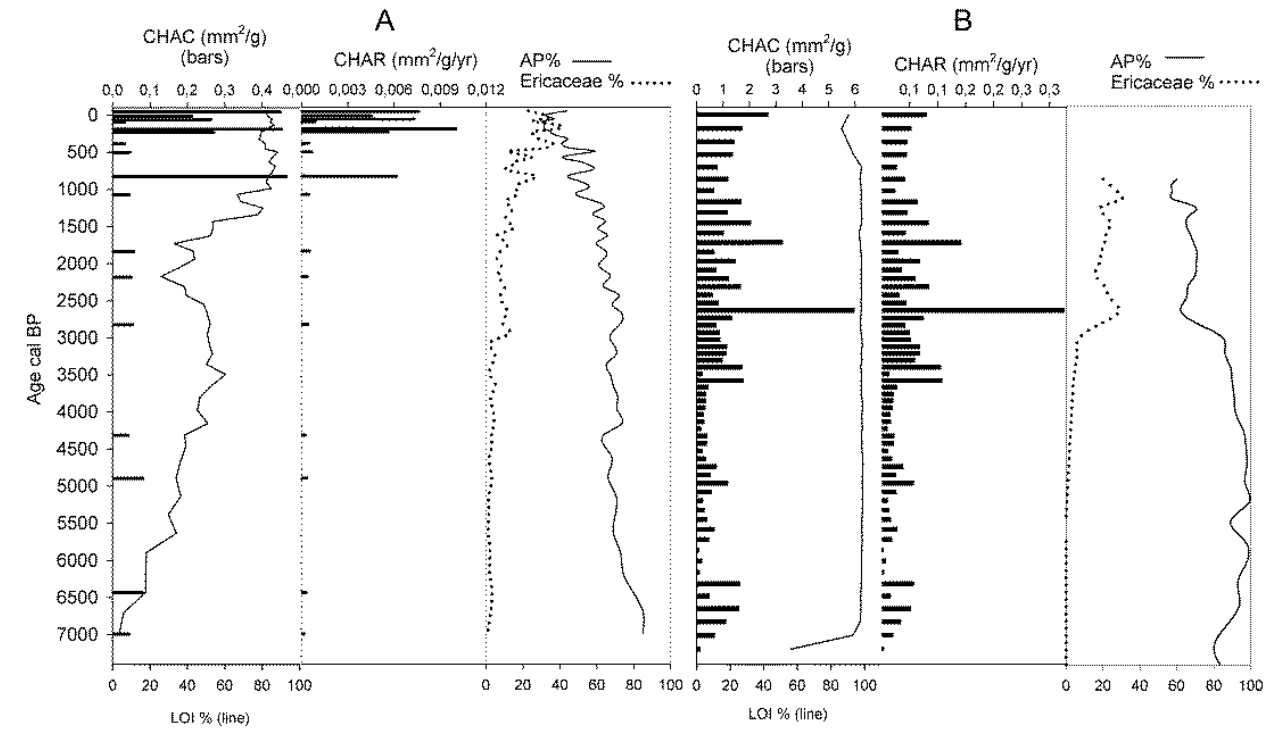

Fig. 5 CHAC, LOI, CHAR and changes in arboreal and Ericaceae pollen at El Sertal (A) and El Cueto de la Avellanosa (B). The pollen values at El Cueto de la Avellanosa have been redrawn based on Mariscal (1983). The fire events detected at El Sertal and El Cueto de la Avellanosa appear to follow a different pattern. At El Cueto de la Avellanosa, CHAR increased ca. 3600 cal years BP and the maximum is seen at ca. 2650 years cal BP, coinciding with Bond cycle 2. At El Sertal, the highest CHAR values were found during the most recent millennium, when there has been a greater local and regional anthropic pressure. 


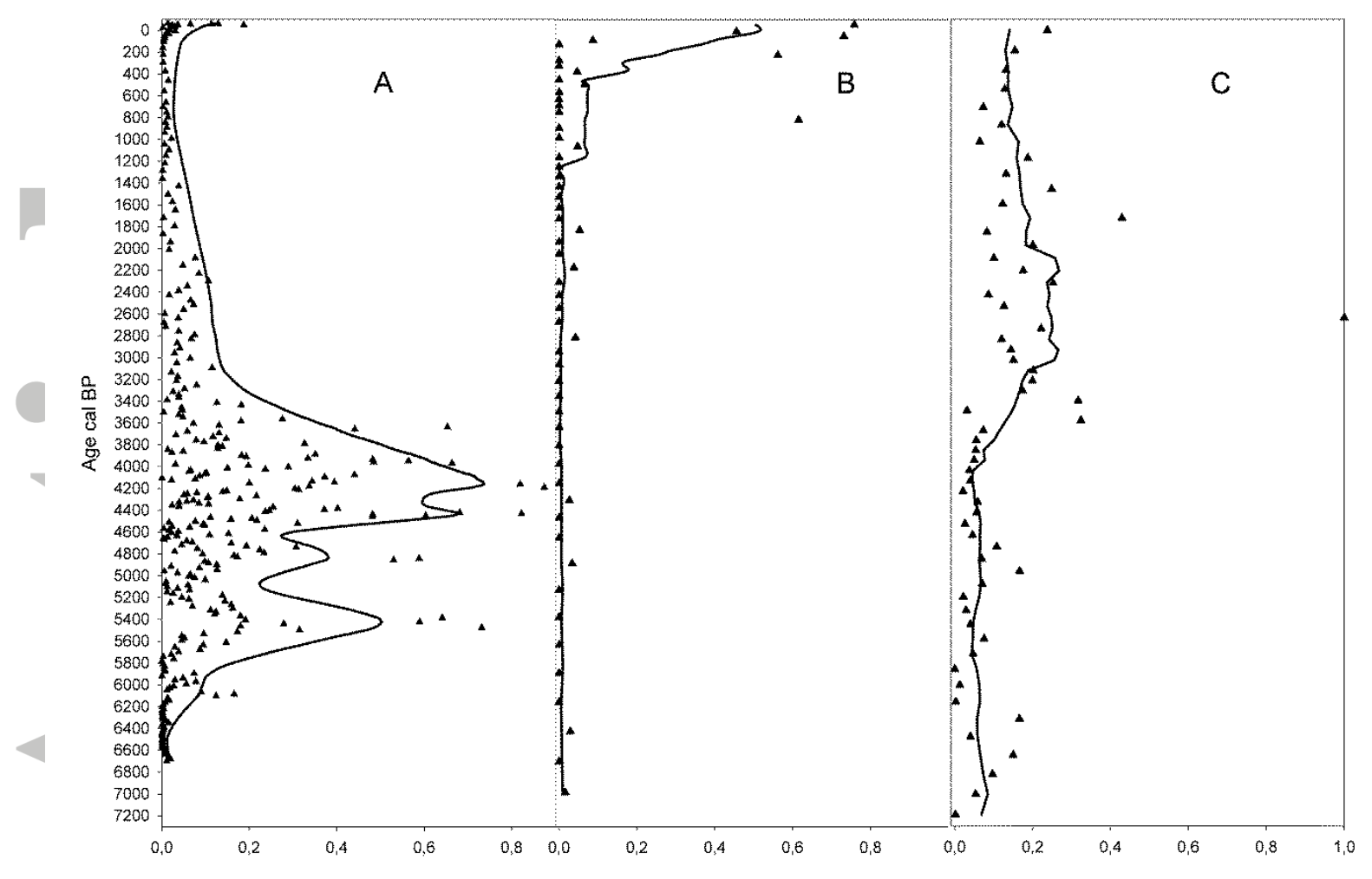

Fig 6. Comparison of CHAR values with rescaled and smoothed values from La Molina (A), El Sertal (B) and El Cueto de la Avellanosa (C). Over the past 7000 years, the intensity and chronology of fire events was unequal at the three sites studied, which can be interpreted as the result of asynchronous human activity in the high and low mountain areas and, at the same time, of the type of fuel involved in each zone. 


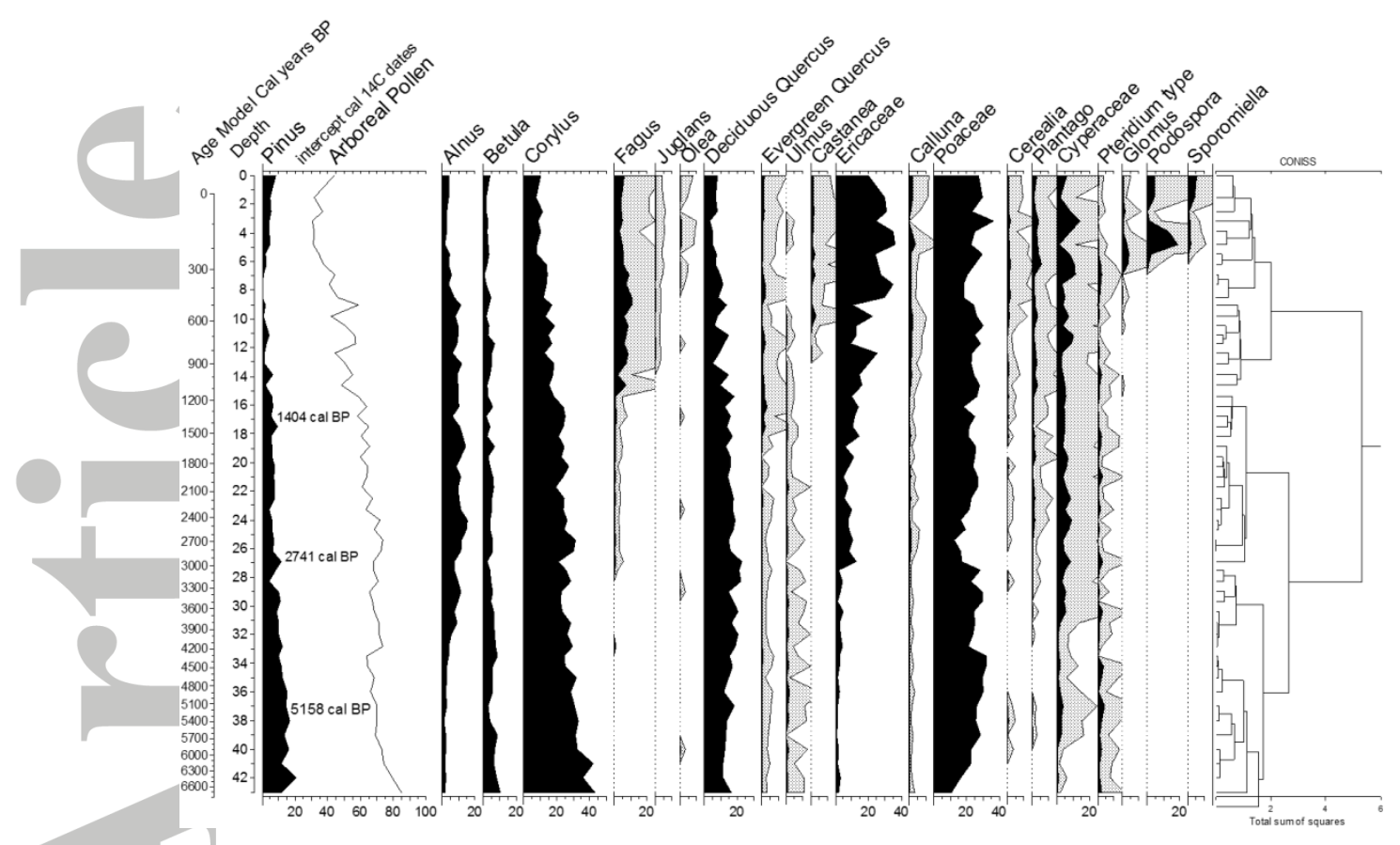

Fig. 7: Main taxa of the El Sertal pollen diagram. The pollen data revealed a continuous decline in forest cover since the Neolithic. Note the significant values of Poaceae, Pteridium, Ericaceae and Cereals, indicating different land management periods and types of human impact. The intensification of fires in the last millennium could well have led to the considerable increase in Fagus. 